\title{
Yield Loss Associated with Different Levels of Stem Rust Resistance in Bread Wheat
}

Tegwe Soko, Seed-Co Zimbabwe Limited, Rattray Arnold Research Station, P.O. Box CH142, Chisipite, Harare, Zimbabwe; Cornelia M. Bender, Department of Plant Sciences, University of the Free State, Bloemfontein 9300, South Africa; Renée Prins, CenGen (Pty) Ltd., Worcester 6850, South Africa; and Department of Plant Sciences, University of the Free State, Bloemfontein 9300, South Africa, and Zacharias A. Pretorius, ${ }^{\dagger}$ Department of Plant Sciences, University of the Free State, Bloemfontein 9300, South Africa

\begin{abstract}
Puccinia graminis f. sp. tritici race Ug99 (syn. TTKSK) has been identified as a major threat to wheat production based on its broad virulence. Despite its importance, the effect of $\mathrm{Ug} 99$ on different types of resistance in wheat has not been thoroughly researched. In field trials conducted with $P$. graminis f. sp. tritici race PTKST (Ug99 race group) over 2 years, AUDPC differentiated the moderately susceptible variety SC Stallion (515) and susceptible entries SC Nduna (995) and Line 37-07 (1634) from those with adult plant resistance (APR). AUDPC of APR varieties W1406 (256),

W6979 (399), and Kingbird (209) was higher than the mean of 25 recorded for the all stage resistant (ASR) variety SC Sky. In fungicide-protected and unprotected plots, race PTKST resulted in a mean yield loss of $21.3 \%$, with susceptible Line 37-03 recording a 47.9\% decrease in grain yield. Yield reduction in APR varieties reached $19.5 \%$ in W1406, whereas the ASR control SC Sky showed a mean loss of $6.4 \%$. Although APR reduced the effects of stem rust on yield and yield components under conditions of high disease pressure, it did not provide the same protection as effective ASR.
\end{abstract}

Ug99 or TTKSK, an African strain of Puccinia graminis Pers. f. sp. tritici Eriks. \& E. Henn., the cause of stem (black) rust, virulent for the widely used $\mathrm{Sr} 31$ resistance gene in wheat (Triticum aestivum L.), was first observed in Uganda in 1998 and characterized in 1999 (Hiebert et al. 2010; Pretorius et al. 2000; Singh et al. 2008). Isolates of $P$. graminis $\mathrm{f}$. sp. tritici belonging to the $\mathrm{Ug} 99$ race group are virulent to a broad spectrum of resistance genes, rendering $90 \%$ of the wheat varieties grown worldwide susceptible to stem rust (Pretorius and Bender 2010; Singh et al. 2011a; 2015). Since first detection of the original $\mathrm{Ug} 99$ isolate, 13 races belonging to the $\mathrm{Ug} 99$ group have been identified with members present in Uganda, Kenya, South Africa, Ethiopia, Sudan, Yemen, Iran, Tanzania, Zimbabwe, Eritrea, Mozambique, Rwanda, and Egypt (Singh et al. 2011a; http:// rusttracker.cimmyt.org). The likely emergence of new Ug99 races will persist to render once effective $S r$ genes ineffective. This was confirmed by Bhavani et al. (2010), who observed that new strains of $\mathrm{Ug} 99$, with added virulence to $\mathrm{Sr} 24$ and $\mathrm{Sr} 36$, resulted in more than half of the TTKSK-resistant lines being susceptible.

Ug99 races TTKSF, TTKSF+Sr9h, and PTKST have been identified in both Zimbabwe and South Africa, while TTKSP has been observed only in South Africa (http://rusttracker.cimmyt.org). In Zimbabwe, stem rust is regularly recorded at Lowveld sites (Mukoyi et al. 2011), whereas in South Africa the disease is most prevalent in the Western Cape (Terefe et al. 2016). The use of resistant varieties is viewed as an important control strategy in both countries. Moreover, resistance must be durable, as utilization of single, racespecific genes has often led to breakdown of resistance due to rapid pathogen population replacement by new virulent races (HerreraFoessel et al. 2008; Pretorius et al. 2017; Singh et al. 2015).

In addition to the threat posed by the Ug99 race group, other highly virulent $P$. graminis f. sp. tritici races not related to Ug99 have recently appeared in Ethiopia, Turkey, Germany, and Sicily (http:// rusttracker.cimmyt.org). Olivera et al. (2015) reported extensive crop failures due to stem rust epidemics, primarily caused by race TKTTF, in the wheat cultivar Digalu (SrTmp) in Ethiopia in 2013-2014. Six

${ }^{\dagger}$ Corresponding author: Z. A. Pretorius; E-mail: pretorza@ufs.ac.za

Funding: National Research Foundation (UID 96099).

Accepted for publication 13 June 2018.

C) 2018 The American Phytopathological Society races, including TKTTF, were detected in Germany in 2013 (Olivera Firpo et al. 2017). The 2016 epidemic in Sicily, which occurred on bread and durum wheat affecting several thousand hectares, was caused by a highly virulent TTTTF race of $P$. graminis $f$. sp. tritici (http://rusttracker.cimmyt.org). According to present knowledge, none of these races have spread to southern Africa, but following examples from other rust pathosystems (Pretorius et al. 2015), such an event is plausible.

Despite the importance of stem rust as a re-emerging disease and emphasis on breeding for more durable resistance types, often expressed as adult plant resistance (APR), little is known about the level of yield protection under epidemic conditions. In this study, the effect of stem rust on yield, yield components, and protein content was studied in wheat cultivars and lines with different types of resistance. Kingbird, W1406, and W6979 are wheat lines known to confer APR (Njau et al. 2010; Prins et al. 2016; Singh et al. 2011a), and Line 37 07 is a stem rust susceptible line selected from a CIMMYT nursery (Prins et al. 2016). Based on previous results, SC Stallion and SC Nduna are Seed-Co commercial varieties considered moderately susceptible and susceptible to PTKST, respectively. Both exhibited fully susceptible seedling infection types and corresponding adult plant scores of 80MRMS and 60S to race PTKST in greenhouse studies (Soko 2018; Soko et al. 2015). Postulated to carry Lr19/Sr25 (Pretorius et al. 2015), SC Sky was used as a check variety for all stage resistance (ASR) based on its low seedling infection type $(; 1)$ and resistant adult plant response (30R) to PTKST (Soko 2018). The degree of yield protection in APR lines was of particular interest in this study.

\section{Materials and Methods}

Experimental design, trial management, and germplasm used. A split-plot design with three replications was used in both the 2014 and 2015 seasons. Main plots were fungicide-sprayed and nonsprayed treatments, whereas subplots were seven wheat varieties or lines. Prosaro (active ingredients $125 \mathrm{~g} /$ liter prothioconazole and $125 \mathrm{~g} /$ liter tebuconazole), a registered fungicide in South Africa, was applied three times during the 2014 season and four times in 2015 . The relevant plots were sprayed at a rate of $400 \mathrm{ml} /$ ha using a backpack sprayer with an attached hand-held boom. Aphox (pirimicarb) was used to control aphids at a rate of $250 \mathrm{~g} / \mathrm{ha}$, while Confidor (imidacloprid) was applied twice at a rate of $290 \mathrm{~g} / \mathrm{ha}$ in 2015 .

Prior to planting, $250 \mathrm{~kg}$ 2:3:4 (38) N-P-K plus $0.5 \% \mathrm{Zn}$ fertilizer was applied per hectare. A seeding rate of $80 \mathrm{~kg} / \mathrm{ha}$ was used with a gross plot size of $24.3 \mathrm{~m}^{2}$ (eight $4-\mathrm{m}$ rows with $0.76-\mathrm{m}$ interrow 
spacing). Each plot consisted of three rows of a respective trial entry flanked by three and two border rows of Line 37-07 on either side. Two susceptible varieties (SC Nduna and Line 37-07), a moderately susceptible variety (SC Stallion), and three APR lines (Kingbird, W1406, and W6979) were used in the study (Table 1). The variety SC Sky with ASR to stem rust was also included. Main plots were separated by eight 4-m rows of Line 37-07. Stem rust-susceptible border rows of Line 37-07 were inoculated on several occasions with fresh urediniospores of Ug99 race PTKST suspended in Soltrol 130 isoparaffinic oil (Chevron Phillips, Borger, Texas). The spore suspension was applied with an ultra-low volume sprayer (ULVA, Micron Group, Bromyard, England) in the late afternoon. As infection assurance, certain sections of inoculated borders were covered with plastic sheeting to create high humidity conditions overnight.

The study was done under bird protection netting during the 2014 and 2015 winter seasons at Greytown, South Africa. Normal wheat agronomic practices were followed during the two seasons of testing.

Yield, yield components, grain protein content, stem rust scores, and data analysis. At harvest ripeness, three rows per treatment were cut and threshed. Net plot yield (g) was converted into $\mathrm{kg} / \mathrm{ha}$ at $12.5 \%$ moisture basis $(\mathrm{mb})$ using the formula:

$$
\begin{aligned}
& \text { Yield }(\mathrm{kg} / \mathrm{ha}) @ 12.5 \% \mathrm{mb}=10 \times(\text { Net yield }(\mathrm{g}) \\
& \times \% \text { moisture @ harvesting }) \text { net plot }\left(\mathrm{m}^{2}\right) \times(100-12.5 \%)
\end{aligned}
$$

A seed counter (NUMIGRAL model) was used to count 1,000 grains from each sample, and an electronic digital scale (DHAUS Scout) was used to record mass of the 1,000 grains (thousand kernel weight $[\mathrm{TKW}]$ ). Test weight, also known as hectolitre mass (HLM) was recorded for each plot using Seedburo's Filling Hopper and Stand equipment. Grain protein (GP) content was determined at $14 \%$ moisture as outlined in AACC International Approved Method 39.10.01 (1999) (AACC International 1999). The percentage loss for grain yield, TKW, HLM, and GP content data were calculated as ([sprayed nonsprayed]/sprayed) $\times 100$.

Stem rust was recorded using the modified Cobb scale where disease severity is the percentage of tissue infected, in combination with host response as immune (0), resistant (R), moderately resistant (MR), moderately susceptible (MS), and susceptible (S) (Roelfs et al. 1992). A stem rust coefficient of infection (SRCI) was calculated by multiplying the severity score and a constant for host response where $\mathrm{R}=0.2$, $\mathrm{MR}=0.4, \mathrm{MS}=0.8$, and $\mathrm{S}=1.0$ (Roelfs et al. 1992). Where necessary, interpolations were used for overlapping response classes. Stem rust was assessed on three and four occasions in 2014 and 2015, respectively. Area under disease progression curve (AUDPC) was calculated according to Campbell and Madden (1991).
GenStat $14^{\text {th }}$ Edition (www.vsni.co.uk) was used to calculate analysis of variance (ANOVA) for each trait in 2014 and 2015. A combined analysis over the two seasons was also performed. Least significance differences (LSD) were used to compare the means for grain yield $(\mathrm{kg} / \mathrm{ha})$, TKW $(\mathrm{g})$, HLM $(\mathrm{kg} / \mathrm{hl})$, grain protein content, and SRCI. The analysis was based on a mixed model where fungicide treatment and variety were fixed, while plots were randomly allocated to the fixed variables. The following model was used:

$$
Y_{i j k}=\mu+\alpha_{i}+\beta_{j}+(\alpha \beta)_{i j}+\mathrm{g}_{i k}+\mathrm{e}_{i j k}
$$

where $Y_{i j k}$ : observation from $i$ th main plot, $j$ th block, and $k$ th subplot, $\mu$ : overall mean,

$\alpha_{i}$ : main plot effect (fungicide treatment) at $i$ th main plot level where $i=1$ (nonsprayed) and 2 (sprayed),

$\beta_{j}$ : subplot effect (variety) at $j$ th subplot level where $j=1 \ldots . .7$,

$\alpha \beta_{i j}$ : interaction effects of main plot by subplot factors (fungicide treatment by variety),

$g_{i k}$ : main plot error distribution,

$e_{i j k}:$ subplot error distribution.

\section{Results}

Rust development. In 2014, the first stem rust score was recorded when most entries were at Zadoks growth stage 71 on October 3, followed by assessments on October 17 and November 4. Final severities recorded on nonsprayed plots were 100S (Line 37-07), 100MSS (SC Nduna), 90MRMS (W6979), 70MRMS (W1406), 50S (SC Stallion), 40MRMS (Kingbird), and 10MR (SC Sky). Stem rust infection on sprayed plots was negligible except for the highly susceptible Line 37-07, which recorded a score of 20S. Moreover, natural leaf rust infection occurred in the trial with Line 37-07 recording $100 \mathrm{~S}$ at the final assessment, W6979 (60S), W1406 (20S), Kingbird (30S), SC Nduna (40S), and SC Sky (0R) in nonsprayed plots. Nonsprayed plots had a higher mean SRCI (15.5) compared with sprayed plots (0.8), indicating a reduction of $94.2 \%$ due to the fungicide treatment (Table 2). SRCI scores for SC Nduna and Line 37-07 on nonsprayed plots were 24.4 and 48.4, respectively, whereas 11.9 was recorded for SC Stallion (Table 2). AUDPC for nonsprayed entries in the moderately susceptible to susceptible category ranged from 343 (SC Stallion) to 1635 (Line 37-07), whereas nonsprayed APR varieties ranged from 129 (Kingbird) to 325 (W6979) (Table 3). SRCI scores for both sprayed and nonsprayed plots for APR varieties were below 12 (Table 2).

In 2015, stem rust was recorded on October 2, 16, 23, and 30. Severities at the final assessment date for nonsprayed plots were $100 \mathrm{~S}$ (Line 37-07 and SC Nduna), 80MSS (W6979), 80MRMS (W1406),

\begin{tabular}{|c|c|c|}
\hline Variety/line & Pedigree & Remarks \\
\hline SC Nduna (Susceptible) & E16 (Unknown) & $\begin{array}{l}\text { White grained CIMMYT introduction released in Zimbabwe } \\
\text { with code E16 in } 1999 \text { (unpublished). }\end{array}$ \\
\hline SC Stallion (Moderately susceptible) & CP1509-88-5-2/W137-6-3 & $\begin{array}{l}\text { A red grained stem rust susceptible Seed-Co variety released in } \\
\text { Zimbabwe in } 2004 \text { (unpublished). }\end{array}$ \\
\hline SC Sky $\left(\mathrm{ASR}^{\mathrm{a}}\right)$ & Smart (Nata/W31-89)/Shield & $\begin{array}{l}\text { Stem rust resistant Seed-Co variety released in Zimbabwe in } \\
2009 \text { (unpublished). Shield (W8-2000 - 1999) is a CIMMYT } \\
\text { introduction with pedigree Seri*4//Aga/6*Yr/3/Seri. }\end{array}$ \\
\hline Line 37-07 (Susceptible) & Kasyob/Genaro-81//Cham4 & $\begin{array}{l}\text { Stem rust susceptible selection from } 2007 \text { Stem Rust Trap } \\
\text { Nursery, South Africa (Prins et al. 2016). }\end{array}$ \\
\hline W1406 $\left(\mathrm{APR}^{\mathrm{b}}\right)$ & Penjamo-62/908- Frontana-1)//Kentana-54-B & $\begin{array}{l}\text { Stem rust resistant line Kenya_TK_42 from Genome Resource } \\
\text { Unit (GRU), Norwich Research Park (Prins et al. 2016). }\end{array}$ \\
\hline W6979 (APR $\left.{ }^{b}\right)$ & $\begin{array}{l}\text { Klein-Atlas/Tobari-66//Centrifen/3/Bluebird/4/ } \\
\text { Kenya-Fahari }\end{array}$ & $\begin{array}{l}\text { Hard, red-grained spring wheat variety with stem rust resistance } \\
\text { from Genome Resource Unit (GRU), Norwich Research Park } \\
\text { and released in Kenya in } 1982 \text { as Kenya-Popo (Prins et al. 2016). }\end{array}$ \\
\hline Kingbird $\left(\mathrm{APR}^{\mathrm{b}}\right)$ & $\begin{array}{l}\text { Tam-200/Tui/6/Pavon-F-76//Carianca-422/ } \\
\text { Anahuac-F-75/5/Bobwhite/Crow//Buckbuck/ } \\
\text { Pavon-F-76/3/Yecora-F-70/4/Trap-1 }\end{array}$ & A CIMMYT variety with APR (Singh et al. 2015). \\
\hline
\end{tabular}
70S (SC Stallion), 50MSS (Kingbird), and 15MRMS (SC Sky).

Table 1. Description of wheat varieties and lines used to study the effects of stem rust on yield, yield components, and protein content

\footnotetext{
${ }^{a}$ ASR: All stage resistance.

b APR: Adult plant resistance.
} 
Nonsprayed plots had a higher SRCI (28.6) compared with sprayed plots (1.2), indicating a reduction of $95.4 \%$ in field response (Table 2). Similar to the previous season, SRCI scores for the moderately susceptible variety SC Stallion (28.2) and susceptible varieties SC Nduna (51.1) and Line 37-07 (64.8) were high on nonsprayed plots. On the contrary, SRCI of APR varieties in nonsprayed plots ranged from 15.1 (Kingbird) to 22.7 (W6979) (Table 2). AUDPC for nonsprayed moderately susceptible to susceptible varieties ranged from 688 (SC Stallion) to 1632 (Line 37-07) (Table 3). SRCI scores for both sprayed and nonsprayed plots for APR varieties were below 23. Nonsprayed AUDPC for APR varieties ranged from 290 (Kingbird) to 473 (W6979) (Table 3). Similar to 2014, leaf rust was first noticed on 2 October, and by 30 October it had caused death of leaves on Line 37-07 and responses of 40MSS on SC Nduna and W6979, 30MSS on SC Stallion, and 10MS on Kingbird. SC Sky was not infected by leaf rust.

Grain yield. Figure 1 summarizes the yield performance of the seven wheat varieties during 2014 and 2015. Sprayed plots had a mean yield of $6,220 \mathrm{~kg} / \mathrm{ha}$ compared with nonsprayed plots at $4,854 \mathrm{~kg} / \mathrm{ha}$. The differences in yield were attributed to varieties $(P<0.01)$ and interaction effects between treatment and varieties $(P<0.05)$. Moderately susceptible to susceptible varieties recorded yield losses that ranged from $17.1 \%$ (SC Stallion) to $46.8 \%$ (Line 37-07), while yield losses for APR varieties ranged from $13.9 \%$ (Kingbird) to $20.2 \%$ (W6979). The ASR variety SC Sky recorded a $10.4 \%$ loss in 2014 .

In 2015 , sprayed plots had a mean yield of $5,509 \mathrm{~kg} / \mathrm{ha}$ that was significantly $(P<0.05)$ higher than yield for the nonsprayed plots $(4,333 \mathrm{~kg} / \mathrm{ha})$. Again, Line 37-07 recorded the highest loss in yield
(49.2\%), while SC Sky gained 1.3\% due to fungicide treatment (Fig. 1). Moderately susceptible to susceptible varieties recorded the highest yield losses, ranging from 25.2\% (SC Stallion) to 49.2\% (Line 37-07), while APR varieties recorded losses between $4.9 \%$ (Kingbird) and $26.6 \%$ (W1406). These yield differences were attributed to treatment $(P<0.05)$, variety, and interaction effects $(P<0.001)$, respectively. In general, grain yield of sprayed plots was higher in 2014 , with a mean of $6,220 \mathrm{~kg} / \mathrm{ha}$ compared with $4,797 \mathrm{~kg} / \mathrm{ha}$ in 2015 . A mean yield loss of $21.3 \%$ was recorded over the two seasons (Table 4).

Thousand kernel weight. Means for TKW for both seasons are summarized in Table 5. In 2014, significant differences $(P<0.01)$ in TKW were observed between sprayed and nonsprayed varieties, with Line 37-07, SC Nduna, and SC Stallion recording the highest losses of 28.1, 13.3, and $17.2 \%$, respectively. Varieties known to show APR recorded lower TKW losses that ranged between $4.1 \%$ for Kingbird and 11.6\% for W1406. During the 2015 season, differences in TKW between sprayed and nonsprayed treatments were significant at $P<0.01$, between varieties $(P<0.001)$, and due to interaction effects $(P<0.001)$. In nonsprayed treatments, the largest reductions in TKW ranged from $28.1 \%$ in SC Stallion to $48.7 \%$ in Line 37-07. Losses in entries with APR ranged from 20.4\% (Kingbird) to $29.6 \%$ (W1406). Over the two seasons, comparing sprayed and nonsprayed plots, stem rust reduced TKW by $20.4 \%(P<$ $0.05)$ (Table 5). Significant $(P<0.001)$ reductions in TKW were also observed between varieties, with SC Stallion recording a $22.1 \%$ loss and Line 37-07, 37.8\% (Table 5). Resistant varieties recorded mean losses that were between $10.6 \%$ for SC Sky and $20.4 \%$ for W1406. Interaction effects between fungicide treatment and variety were

Table 2. Stem rust coefficient of infection (SRCI) for seven fungicide sprayed and nonsprayed wheat varieties during 2014 and 2015

\begin{tabular}{|c|c|c|c|c|c|c|c|c|c|}
\hline \multirow[b]{2}{*}{ Variety } & \multicolumn{3}{|c|}{ SRCI 2014} & \multicolumn{3}{|c|}{ SRCI 2015} & \multicolumn{3}{|c|}{ Mean SRCI over years } \\
\hline & Sprayed & Nonsprayed & $\%$ red $^{a}$ & Sprayed & Nonsprayed & $\%$ red $^{\mathbf{a}}$ & Sprayed & Nonsprayed & $\%$ red $^{a}$ \\
\hline SC Nduna & 0.3 & 24.4 & $98.8^{+}$ & 1.7 & 51.1 & $96.7^{+}$ & 1.0 & 37.8 & $97.4^{+}$ \\
\hline SC Stallion & 2.3 & 11.9 & $80.7^{+}$ & 0.6 & 28.2 & $97.9^{+}$ & 1.5 & 20.1 & $92.5^{+}$ \\
\hline SC Sky & 0.0 & 0.5 & 100.0 & 0.3 & 2.4 & 88.0 & 0.2 & 1.5 & 86.7 \\
\hline Line 37-07 & 2.3 & 48.4 & $95.3^{+}$ & 4.1 & 64.8 & $93.7^{+}$ & 3.2 & 56.6 & $94.3^{+}$ \\
\hline W1406 & 0.0 & 7.6 & $100.0^{+}$ & 0.3 & 15.8 & $98.1^{+}$ & 0.2 & 11.7 & $98.3^{+}$ \\
\hline W6979 & 0.3 & 11.1 & $97.3^{+}$ & 1.0 & 22.7 & $95.6^{+}$ & 0.7 & 16.9 & $95.9^{+}$ \\
\hline Kingbird & 0.6 & 4.6 & 87.0 & 0.3 & 15.1 & $98.0^{+}$ & 0.5 & 9.9 & $94.9^{+}$ \\
\hline Mean & 0.8 & 15.5 & 94.2 & 1.2 & 28.6 & 95.4 & 1.0 & 22.0 & 95.5 \\
\hline Source & $\mathbf{s e}^{\mathbf{b}}$ & $\mathbf{L S D}^{\mathrm{c}}$ & F. Sigd & $\mathbf{s e}^{\mathbf{b}}$ & $\mathbf{L S D}^{\mathbf{c}}$ & F. Sig ${ }^{d}$ & $\mathbf{s e}^{\mathbf{b}}$ & $\mathbf{L S D}^{\mathbf{c}}$ & F. Sigd \\
\hline Treatment & 3.88 & 5.48 & NS & 1.69 & 10.27 & $* *$ & 1.9 & 3.50 & $* * *$ \\
\hline Variety & 2.33 & 3.30 & $* * *$ & 1.44 & 4.20 & $* * *$ & 1.0 & 6.54 & $* *$ \\
\hline Year & & & & & & & 1.0 & 3.50 & $* *$ \\
\hline Treatment*variety & 4.93 & 6.98 & $* * *$ & 2.53 & 8.10 & $* * *$ & 2.7 & 9.3 & $* *$ \\
\hline Treatment*year & & & & & & & 1.4 & 4.9 & $* *$ \\
\hline Variety*year & & & & & & & 2.7 & 9.3 & NS \\
\hline Treatment*variety*year & & & & & & & 3.8 & 13.1 & NS \\
\hline
\end{tabular}

a Percentage reduction in SRCI $=((\text { Nonsprayed SRCI }- \text { Sprayed SRCI }) / \text { Non-Sprayed SRCI })^{*} 100$.

$\mathrm{b}$ se: standard error of means.

${ }^{c}$ LSD: Least Significant Difference at $0.05 \%$.

${ }^{\mathrm{d}}$ F. Sig: Significance level at $P<0.05(*), P<0.01(* *), P<0.001(* *)$ and Not significant (NS). Significant SRCI reduction (gain) between sprayed and nonsprayed at $P<0.05$ according to LSD is indicated by ${ }^{+}$.

Table 3. Area under disease progress curve (AUDPC) for seven fungicide sprayed and nonsprayed wheat varieties during 2014 and 2015

\begin{tabular}{|c|c|c|c|c|c|c|c|c|c|}
\hline \multirow[b]{2}{*}{ Variety } & \multicolumn{3}{|c|}{ AUDPC 2014} & \multicolumn{3}{|c|}{ AUDPC 2015} & \multicolumn{3}{|c|}{ Mean AUDPC over years } \\
\hline & Sprayed & Nonsprayed & $\overline{\text { Difference }^{\mathbf{a}}}$ & Sprayed & Nonsprayed & $\overline{\text { Difference }^{a}}$ & Sprayed & Nonsprayed & Difference $^{\mathbf{a}}$ \\
\hline SC Nduna & 11.0 & 767.7 & 756.8 & 29.4 & 1223.1 & 1193.7 & 20.2 & 995.4 & 975.2 \\
\hline SC Stallion & 63.0 & 343.0 & 280.0 & 8.4 & 687.5 & 679.1 & 35.7 & 515.2 & 479.3 \\
\hline SC Sky & 0.0 & 14.4 & 14.4 & 4.9 & 35.0 & 30.1 & 2.5 & 24.7 & 22.3 \\
\hline Line $37-07$ & 63.0 & 1635.4 & 1572.4 & 76.2 & 1632.0 & 1556.9 & 69.6 & 1633.7 & 1564.1 \\
\hline W1406 & 0.9 & 208.7 & 207.8 & 4.2 & 303.9 & 299.7 & 2.6 & 256.3 & 253.7 \\
\hline W6979 & 7.2 & 324.9 & 317.7 & 16.5 & 472.5 & 456.1 & 11.8 & 398.7 & 386.9 \\
\hline Kingbird & 17.1 & 128.9 & 111.8 & 4.6 & 289.8 & 285.2 & 10.8 & 209.3 & 198.5 \\
\hline Mean & 23.2 & 489.0 & 465.8 & 20.6 & 663.4 & 642.8 & 21.9 & 576.2 & 554.3 \\
\hline
\end{tabular}

${ }^{\text {a }}$ Difference $=$ Nonsprayed AUDPC - Sprayed AUDPC. 
significant $(P<0.01)$, with susceptible varieties benefiting when sprayed. Seasonal differences in TKW were highly significant $(P<$ 0.001 ), with a TKW loss of $12.2 \%$ in 2014 compared with $29 \%$ for 2015. Fungicide treatment and seasonal interaction effects were highly significant $(P<0.001)$, with a mean TKW of $41.1 \mathrm{~g}$ and $37.2 \mathrm{~g}$ for sprayed varieties in 2014 and 2015, respectively. TKW for nonsprayed treatments declined from $36.1 \mathrm{~g}$ in 2014 to $26.4 \mathrm{~g}$ in 2015 (Table 5).

Test density (kg/hl). During 2014, test density ranged from $74 \mathrm{~kg} /$ $\mathrm{hl}$ (W1406) to $81 \mathrm{~kg} / \mathrm{hl}$ (Line 37-07) when sprayed and from $70 \mathrm{~kg} / \mathrm{hl}$ (W1406) to $78 \mathrm{~kg} / \mathrm{hl}$ (Kingbird) when nonsprayed (Table 6). When sprayed, Line 37-07 recorded a $12.4 \%$ gain, while an average benefit of $5.4 \%$ was recorded on sprayed plots as compared with nonsprayed (Table 6). Significant differences in test density were due to treatment $(P<0.01)$, variety $(P<0.001)$, and interaction effects of treatment by variety $(P<0.05)$. In the second season, again higher test densities were recorded on sprayed plots (Table 6), ranging from $67 \mathrm{~kg} / \mathrm{hl}$ for Kingbird and W1406 to $71 \mathrm{~kg} / \mathrm{hl}$ for SC Nduna and W6979, respectively. Mean test density for all treatments in $2015(64 \mathrm{~kg} / \mathrm{hl})$ was lower than in $2014(76 \mathrm{~kg} / \mathrm{hl})$. Susceptible varieties recorded higher losses in test density (13 to 30\%) when compared with APR varieties (7 to $16.4 \%$ ) (Table 6). Taking both seasons into consideration, sprayed plots $(74 \mathrm{~kg} / \mathrm{hl})$ had a higher test density than nonsprayed plots $(66 \mathrm{~kg} / \mathrm{hl})$. APR varieties recorded lower test density reductions (4 to $11.3 \%$ ) as opposed to those classified as moderately susceptible to susceptible (9.5 to $20 \%$ ) (Table 6).

Grain protein content. Data on GP content of all varieties for the 2014 and 2015 seasons are presented in Table 7. In 2014, varieties were significantly different $(P<0.001)$ in GP content, ranging from $10.59 \%$ for SC Sky to $12.15 \%$ for W6979 when sprayed. In nonsprayed treatments, GP ranged from $9.95 \%$ (Line 37-07) to $12.78 \%$ (W1406). Five of the seven varieties (SC Nduna, SC Stallion, SC
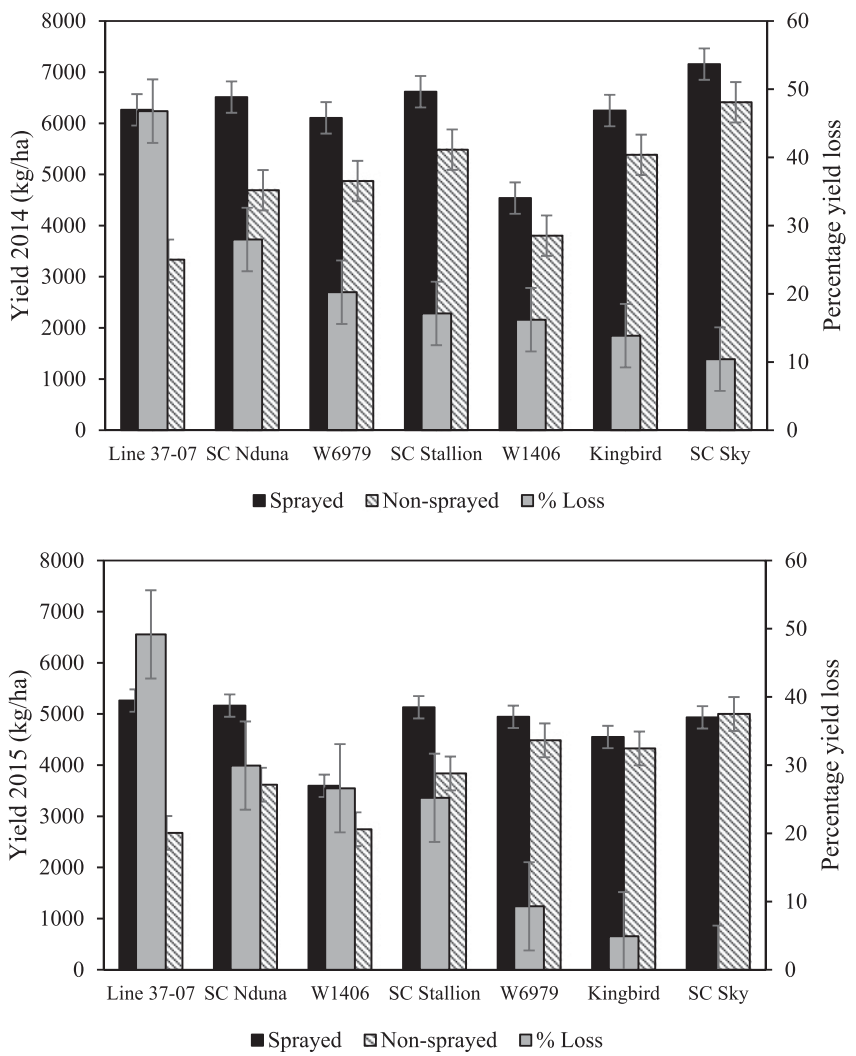

Fig. 1. Sprayed and nonsprayed mean grain yield $(\mathrm{kg} / \mathrm{ha})$ and percentage yield loss in seven wheat varieties in 2014 (top) and 2015 (bottom). Line 37-07 and SC Nduna are susceptible, SC Stallion is moderately susceptible, W6979, W1406, and Kingbird carry adult plant resistance and SC Sky is all stage resistant to stem rust. Error bars represent standard error. Entries were ranked from left to right according to percentage yield loss. In 2015, nonsprayed treatments of SC Sky yielded 1.3\% more than sprayed treatments.
Sky, W1406, and Kingbird) recorded lower GP contents when sprayed than nonsprayed. Only Line 37-07 and W6979 had GP content increases of 11.6 and $2 \%$, respectively, when sprayed. Significant differences in GP content $(P<0.05)$ were observed on Line 37-07, W1406, and Kingbird. In 2015, differences due to fungicide treatment, varieties, and interaction effects were significant at $P<0.05, P<0.01$, and $P<0.05$, respectively. Spraying resulted in higher mean GP content $(13.53 \%)$ compared with nonsprayed (12.65\%) (Table 7). All varieties, except SC Sky, recorded higher protein contents when sprayed. Differences were significant $(P<0.05)$ for SC Stallion, Line 37, and W6979. Taking both seasons into account, spraying resulted in higher GP content, although the trend varied from variety to variety. SC Nduna, SC Sky, W1406, and Kingbird had higher protein contents when not sprayed than when sprayed (Table 7).

\section{Discussion}

Stem rust has been a recurrent threat to wheat production, causing severe yield losses throughout recorded history (Dean et al. 2012). Furthermore, commercial losses due to stem rust have impacted on national and global policies on disease management. In North Dakota, South Dakota, and Minnesota in the United States, 5.67 million ha of wheat were seriously affected by stem rust in 1916, leading to adoption of the barberry eradication policy the following year (Roelfs 1982). In Australia, periodic stem rust outbreaks have caused extensive damage since 1889 , but the 1973 epidemic resulting in 25 to $30 \%$ losses (Hodson 2011), worth more than AU\$200 million, was described as "the most severe in the Australian wheat industry" by Watson and Butler as cited by Park (2007). A follow-up conference in 1974 gave rise to a highly successful, nationally coordinated rust control approach (Hodson 2011). In Africa, a modern semidwarf variety 'Enkoy' covered large areas in Ethiopia when stem rust caused an average yield loss of 42\% in 1993-94 (Dubin and Brennan 2009). Olivera et al. (2015) reported almost 100\% yield loss on the Ethiopian wheat cultivar Digalu, caused by a stem rust race that did not belong to the Ug99 group, during November 2013 to January 2014.

Losses due to stem rust have previously been quantified. DillMacky et al. (1990) recorded 59\% yield loss on a susceptible wheat variety 'Oxley' compared with the susceptible barley varieties 'Corvette' (22\%) and 'Galleon' (48\%). In fungicide efficacy experiments in Australia using different active ingredients, rates, and timing of applications, Loughman et al. (2005) reported yield losses between 10 and $45 \%$. In South Africa, previous studies have attributed a mean

Table 4. Mean grain yield $(\mathrm{kg} / \mathrm{ha})$ for seven fungicide sprayed and nonsprayed wheat varieties during two seasons

\begin{tabular}{lccc}
\hline Variety & Sprayed & Nonsprayed & \% reduction \\
\hline SC Nduna & 5838 & 4155 & $28.8^{+}$ \\
SC Stallion & 5874 & 4661 & 20.7 \\
SC Sky & 6095 & 5705 & 6.4 \\
Line 37-07 & 5763 & 3004 & $47.9^{+}$ \\
W1406 & 4067 & 3275 & 19.5 \\
W6979 & 5526 & 4678 & 15.3 \\
Kingbird & 5400 & 4854 & 10.1 \\
Mean & $\mathbf{5 5 0 9}$ & $\mathbf{4 3 3 3}$ & $\mathbf{2 1 . 3}$ \\
Source & $\mathbf{s e} \mathbf{b}$ & $\mathbf{L S D}$ & $\mathbf{F . ~ S i g}$ \\
Treatment & 245.9 & 1496.2 & NS \\
Variety & 134.3 & 391.9 & $* * *$ \\
Year & 126.5 & 366.3 & $* * *$ \\
Treatment*variety & 302.3 & 1139.2 & $* * *$ \\
Treatment*year & 276.5 & 1205.1 & $\mathrm{NS}$ \\
Variety*year & 272.0 & 775.5 & NS \\
Treatment*variety*year & 450.9 & 1340.5 & $\mathrm{NS}$ \\
\hline
\end{tabular}

${ }^{\text {a }}$ Percentage reduction $=(($ Sprayed - Nonsprayed $) /$ Sprayed $) * 100$. Significant reduction in yield between sprayed and nonsprayed at $P<0.05$ according to LSD is indicated by ${ }^{+}$

$\mathrm{b}$ se: standard error of means.

${ }^{\mathrm{c}}$ LSD: Least Significant Difference at $0.05 \%$.

${ }^{\mathrm{d}}$ F. Sig.: Significance level at $P<0.05(*), P<0.01(* *), P<0.001(* * *)$ and Not significant (NS). 
yield loss of $35 \%$ over a range of genotypes to stem rust (Pretorius et al. 2007). Despite the re-emergence of stem rust as an important disease of wheat during recent years (Singh et al. 2015), few studies have quantified the effects of $\mathrm{Ug} 99$ on yield and associated traits in present-day varieties, in particular those that carry APR. Many studies have mentioned that APR, which is the current focus in several breeding programs, can provide resistance to one, or even multiple pathogen species, with expectations of durability (Pretorius et al. 2017; Singh et al. 2015; Yu et al. 2011).

In the current study, mean AUDPC and grain yield loss for the susceptible control Line 37-07 were 1,634 and 48\%, respectively. Although yield loss in Line 37-07 is inflated by leaf rust infection, it is within the range of losses previously reported for stem rust. Studying the effects of race Ug99 on grain yield and yield components using 15 bread wheat varieties over two seasons, Macharia and Wanyera (2012) recorded mean grain yield losses ranging from 6 to $66 \%$. Wanyera et al. (2016) increased grain yield by $66 \%$, grain weight by $42 \%$, and hectolitre mass by $17 \%$ in a fungicide trial using Nativo 300 SC (trifloxystrobin 100 g/liter + tebuconazole 200 $\mathrm{g} /$ liter). Moreover, it is possible that some yield advantage was provided by fungicide applications in control plots. The growth regulating properties of certain fungicide groups, including the triazoles, have often been studied and were summarized by Craven et al. (2017). Wu and Von Tiedemann (2001) reported that epoxiconazole delayed wheat senescence under greenhouse conditions, and Cromey et al. (2004) showed that tebuconazole application prolonged green leaf area in wheat for about 2 days across different trials in New Zealand. However, the effects of fungicides on leaf senescence appear complex and could include host physiology changes, protection against pathogens, endophytes, and other phylloplane microorganisms, environmental influences, and yield potential (Cook et al. 1999; Cromey et al. 2004). In sorghum, Craven et al. (2017) concluded that fungicides could not be relied upon to delay senescence and improve yield in the absence of disease. In a previous South African study

Table 5. Thousand kernel weight (TKW) for seven fungicide sprayed and nonsprayed wheat varieties during 2014 and 2015

\begin{tabular}{|c|c|c|c|c|c|c|c|c|c|}
\hline \multirow[b]{2}{*}{ Variety } & \multicolumn{3}{|c|}{ TKW (g) 2014} & \multicolumn{3}{|c|}{ TKW (g) 2015} & \multicolumn{3}{|c|}{ Mean TKW (g) over years } \\
\hline & Sprayed & Nonsprayed & $\%$ red $^{\mathbf{a}}$ & Sprayed & Nonsprayed & $\%$ red $^{a}$ & Sprayed & Nonsprayed & $\%$ red $^{\mathbf{a}}$ \\
\hline SC Nduna & 37.7 & 32.7 & $13.3^{+}$ & 36.0 & 22.3 & $38.0^{+}$ & 36.8 & 27.5 & $25.3^{+}$ \\
\hline SC Stallion & 40.7 & 33.7 & $17.2^{+}$ & 34.3 & 24.7 & $28.1^{+}$ & 37.5 & 29.2 & $22.1^{+}$ \\
\hline SC Sky & 40.3 & 38.7 & 4.12 & 35.0 & 28.7 & $18.1^{+}$ & 37.7 & 33.7 & 10.6 \\
\hline Line $37-07$ & 42.7 & 30.7 & $28.1^{+}$ & 39.0 & 20.0 & $48.7^{+}$ & 40.8 & 25.3 & $37.8^{+}$ \\
\hline W1406 & 37.3 & 33.0 & $11.6^{+}$ & 36.0 & 25.3 & $29.6^{+}$ & 36.7 & 29.2 & $20.4^{+}$ \\
\hline W6979 & 48.3 & 45.0 & 6.9 & 44.3 & 35.0 & $21.1^{+}$ & 46.3 & 40.0 & $13.6^{+}$ \\
\hline Kingbird & 40.7 & 39.0 & 4.1 & 36.0 & 28.7 & $20.4^{+}$ & 38.3 & 33.3 & $13.1^{+}$ \\
\hline Mean & 41.1 & 36.1 & 12.2 & 37.2 & 26.4 & $29.0^{+}$ & 39.2 & 31.2 & $20.4^{+}$ \\
\hline Source & $\mathbf{s e}^{\mathrm{b}}$ & $\mathbf{L S D}^{\mathrm{c}}$ & F. Sigd & $\mathbf{s e}^{\mathrm{b}}$ & $\mathbf{L S D}^{\mathrm{c}}$ & F. Sigd & $\mathbf{s e}^{\mathrm{b}}$ & $\mathbf{L S D}^{\mathrm{c}}$ & F. Sigd. \\
\hline Treatment & 0.881 & 5.359 & NS & 0.609 & 3.705 & $* *$ & 0.7 & 4.2 & $*$ \\
\hline Variety & 1.269 & 3.705 & $* *$ & 0.716 & 2.091 & $* * *$ & 0.8 & 2.5 & $* * *$ \\
\hline Year & & & & & & & 0.4 & 3.9 & $* * *$ \\
\hline Treatment*variety & 1.881 & 5.544 & NS & 1.118 & 3.362 & $* * *$ & 1.3 & 1.0 & $* *$ \\
\hline Treatment*year & & & & & & & 0.7 & 3.4 & $* * *$ \\
\hline Variety*year & & & & & & & 1.1 & 3.1 & NS \\
\hline Treatment*variety*year & & & & & & & 1.6 & 4.6 & NS \\
\hline
\end{tabular}

a Percentage reduction in TKW $=(($ Sprayed TKW - Nonsprayed TKW $) /$ Sprayed TKW $) * 100$.

$\mathrm{b}$ se: standard error of means.

${ }^{\mathrm{c}}$ LSD: Least Significant Difference at $0.05 \%$

${ }^{\mathrm{d}}$ F. Sig.: Significance level at $P<0.05(*), P<0.01(* *), P<0.001(* * *)$ and Not significant (NS). Significant reduction (gain) between sprayed and nonsprayed at $P<0.05$ according to LSD is indicated by ${ }^{+}$.

Table 6. Hectolitre mass (HLM) for seven fungicide sprayed and nonsprayed wheat varieties during 2014 and 2015

\begin{tabular}{|c|c|c|c|c|c|c|c|c|c|}
\hline \multirow[b]{2}{*}{ Variety } & \multicolumn{3}{|c|}{ HLM (kg/hl) 2014} & \multicolumn{3}{|c|}{ HLM (kg/hl) 2015} & \multicolumn{3}{|c|}{ Mean HLM $(\mathrm{kg} / \mathrm{hl})$ over years } \\
\hline & Sprayed & Nonsprayed & $\%$ red $^{a}$ & Sprayed & Nonsprayed & $\%$ red $^{a}$ & Sprayed & Nonsprayed & $\%$ red $^{a}$ \\
\hline SC Nduna & 79 & 73 & $7.6^{+}$ & 71 & 57 & $19.7^{+}$ & 75 & 65 & $13.3^{+}$ \\
\hline SC Stallion & 79 & 74 & $6.3^{+}$ & 69 & 60 & $13.0^{+}$ & 74 & 67 & $9.5^{+}$ \\
\hline SC Sky & 78 & 76 & 2.6 & 70 & 61 & $12.9^{+}$ & 74 & 68 & $8.1^{+}$ \\
\hline Line $37-07$ & 81 & 71 & $12.4^{+}$ & 70 & 49 & $30.0^{+}$ & 75 & 60 & $20.0^{+}$ \\
\hline W1406 & 74 & 70 & $5.4^{+}$ & 67 & 56 & $16.4^{+}$ & 71 & 63 & $11.3^{+}$ \\
\hline W6979 & 80 & 77 & $3.8^{+}$ & 71 & 66 & $7.0^{+}$ & 75 & 72 & $4.0^{+}$ \\
\hline Kingbird & 78 & 78 & 0.0 & 67 & 60 & $10.5^{+}$ & 72 & 69 & $4.2^{+}$ \\
\hline Mean & 78 & 74 & $5.4^{+}$ & 69 & 59 & $15.6^{+}$ & 74 & 66 & $10.8^{+}$ \\
\hline Source & $\mathbf{s e}^{\mathrm{b}}$ & $\mathbf{L S D}^{\mathrm{c}}$ & F. Sig ${ }^{d}$ & $\mathbf{s e}^{\mathrm{b}}$ & $\mathbf{L S D}^{\mathbf{c}}$ & F. Sig ${ }^{d}$ & $\mathbf{s e}^{\mathrm{b}}$ & $\mathbf{L S D}^{\mathrm{c}}$ & F. Sig ${ }^{\mathrm{d}}$ \\
\hline Treatment & 0.1 & 0.9 & $* *$ & 0.9 & 5.4 & $*$ & 0.5 & 3.1 & $* *$ \\
\hline Variety & 0.9 & 2.6 & $* * *$ & 1.1 & 3.3 & $* * *$ & 0.9 & 2.6 & $* * *$ \\
\hline Year & & & & & & & 0.3 & 0.7 & $* * *$ \\
\hline Treatment*variety & 1.2 & 3.4 & $*$ & 1.7 & 5.1 & $* * *$ & 1.3 & 3.8 & $* * *$ \\
\hline Treatment*year & & & & & & & 0.6 & 2.5 & $* * *$ \\
\hline Variety*year & & & & & & & 1.0 & 2.9 & $* * *$ \\
\hline Treatment* variety*year & & & & & & & 1.5 & 4.2 & NS \\
\hline
\end{tabular}

a Percentage reduction $=((\text { Sprayed HLM }- \text { Nonsprayed HLM }) / \text { Sprayed HLM })^{*} 100$.

${ }^{b}$ se: standard error of means.

${ }^{\mathrm{c}}$ LSD: Least Significant Difference at $0.05 \%$.

${ }^{\mathrm{d}}$ F. Sig.: Significance level at $P<0.05(*), P<0.01(* *), P<0.001(* * *)$ and Not significant (NS). Significant reduction in hectolitre mass between sprayed and nonsprayed at $P<0.05$ according to LSD is indicated by ${ }^{+}$. 
on wheat, no yield increases were obtained when fungicides were applied in the absence of disease (Boshoff et al. 2003). The present study did not allow a quantification of green foliage retention, as several entries matured earlier due to excessive stem rust severity.

SC Nduna (AUDPC 995 and SRCI 37.8) and SC Stallion (AUDPC 515 and SRCI 20.1) recorded relatively high stem rust severities over the two seasons and mean yield losses of 29 and $21 \%$, respectively. Previous genotyping work by Soko et al. (2015) postulated SC Nduna to carry $\mathrm{Sr} 31$ and SC Stallion $\mathrm{Sr} 2+\mathrm{Sr} 31$. Both SC Nduna and SC Stallion may also carry the $L r 46 / Y r 29 / S r 58$ gene. Since $S r 31$ is not effective to race PTKST, the high disease severity and associated loss in SC Nduna was expected. However, some protection was provided by $\mathrm{Sr} 2$ and $\mathrm{Sr} 58$ in SC Stallion as reflected in the traits measured. Over the two seasons, SC Nduna had higher losses in yield, TKW, and HLM when compared with SC Stallion. For GP content, SC Nduna gained $0.1 \%$ compared with a $5.4 \%$ loss in SC Stallion.

Among the three APR lines, Kingbird had the best protection, with a yield loss of $10.1 \%$ over two seasons. It also had the lowest losses in TKW (13.1\%) and HLM (4.2\%) when compared to the APR lines W1406 and W6979. Nonsprayed plots of Kingbird had an average SRCI of 9.9 over two seasons, which was the lowest among the APR lines. Singh et al. (2011a) reported that Kingbird was susceptible in seedling tests with Ug99 but showed high levels of adult plant resistance in the field trials in Kenya and Ethiopia. This was confirmed by field scores in the current study that ranged from 0 to TMS (2014) and 0 to 50MSS (2015). Similarly, Njau et al. (2010) observed that Kingbird was susceptible at the seedling stage (infection type $3+\mathrm{C}$ ) but with good APR, confirmed by scores ranging from $5 \mathrm{M}$ to 5MSS, over four seasons of testing in Kenya. Kingbird also showed pseudo black chaff, a morphological marker for $\mathrm{Sr}$, a trait confirmed by Mago et al. (2011). Although $\mathrm{Sr} 2$ is an important component when combined with resistance loci such as $\mathrm{Lr} 46 / \mathrm{Yr} 29 / \mathrm{Pm} 39 /$ Sr58 or $L r 34 / Y r 18 / P m 38 / S r 57$ (Bhavani et al. 2011), the slow rusting phenotype conferred by the gene alone was not adequate under heavy disease pressure in Kenya (Njau et al. 2009; Singh et al. 2006). Bhavani et al. (2011) postulated the additive effects of three to four genes involved in stem rust resistance in Kingbird with QTL on chromosomes 1AL, 3BS ( $\mathrm{Sr} 2$ ), 5BL (minor gene involved in $\mathrm{Sr} 2 \mathrm{com}-$ plex), 7A, and 7DS (pleiotropic gene Lr34/Yr18/Sr57). The losses sustained by SC Stallion carrying $S r 2$ in combination with the ineffective $S r 31$ gene in the present study supported previous reports that $\mathrm{Sr} 2$ alone does not provide sufficient protection against stem rust in epidemic situations.
W1406 had the highest yield loss among the three APR lines, i.e., $19.5 \%$ over two seasons. The lower yields were supported by a decrease in TKW and HLM of 20.4 and $11.3 \%$, respectively, over two seasons. This line recorded a $4.8 \%$ gain in GP content that might be due to low carbohydrate accumulation as indicated by its low HLM. The nonsprayed SRCI of 11.7 overall was second best among the three APR lines. Over the two seasons, AUDPC for W1406 ranged from 209 in 2014 to 304 in 2015 , whereas the SRCI range was 7.6 to 15.8. The higher disease score in 2015 is reflected in the higher yield loss during that season. Field scores for W1406 were higher than those recorded by Prins et al. (2016), who noted 0R to 5R in 2009 at Njoro (off and main seasons), 10R in 2011 at Greytown, and between TR and 15MR over 4 years of field testing in a doubled haploid (DH) field trial in South Africa. In their genetic diversity studies on African germplasm using diversity arrays technology (DArT), simple sequence repeats (SSR) and KASP SNP markers, Prins et al. (2016) identified four QTL that contributed to stem rust resistance in W1406, i.e., Lr34/Yr18/Sr57, QSr-ufs-3B, QSr-ufs$4 D$, and $Q S r-u f s-2 B$. Major stem rust resistance effects were attributed to $L r 34 / Y r 18 / S r 57$ and $Q S r-u f s-4 D$, while the rest had a minor effect explaining less than $9 \%$ of the phenotypic variance observed.

The APR line W6979 recorded a mean yield loss of $15.3 \%$ over two seasons. In terms of yield components, W6979 lost $13.6 \%$ in TKW and 4\% HLM. These losses were lower than observed for W1406. The small loss in HLM is the reason why the yield of W6979 was not severely affected. W6979 experienced a 7.4\% reduction in GP content over the two seasons. In both seasons, terminal stem rust severity on W6979 was higher than would be expected within the APR category. Hence, the nonsprayed SRCI of 16.9 and AUDPC of 399 were the highest among the three APR lines but were not reflected in the yield loss. Macharia and Wanyera (2012) recorded a yield loss of $51 \%$ in Kenya Popo (=W6979) in a study to establish the effects of Ug99 in Kenya. Despite a seedling infection type of $3+$, the line had a mean field severity score of $2.3 \%$ when inoculated with TTKSK in Kenya (Bajgain et al. 2016). Njau et al. (2009) reported a seedling infection type of 3 for TTKS in greenhouse tests, and a mean severity of $35 \%$ in field trials at Njoro. Studies by Prins et al. (2016) indicated that W6979 had field scores ranging from $0 \mathrm{R}$ to $5 \mathrm{R}$ in 2009 at Njoro (off and main seasons), 40R in 2011 at Greytown, and between TR and 30MR over 4 years of field testing in a DH field trial in South Africa. Their mapping work postulated that W6979 has five QTL ( $\operatorname{rr34/Yr18/Sr57,QSr-}$ $u f s-6 A, Q S R-u f s-2 D, Q S r-u f s-3 D$, and $Q S r-u f s-2 B)$ responsible for

Table 7. Grain protein (GP) content for seven fungicide sprayed and nonsprayed wheat varieties during 2014 and 2015

\begin{tabular}{|c|c|c|c|c|c|c|c|c|c|}
\hline \multirow[b]{2}{*}{ Variety } & \multicolumn{3}{|c|}{ GP content $(\%) 2014$} & \multicolumn{3}{|c|}{ GP content $(\%) 2015$} & \multicolumn{3}{|c|}{ Mean GP content $(\%)$ over years } \\
\hline & Sprayed & Nonsprayed & $\%$ red $^{\mathbf{a}}$ & Sprayed & Nonsprayed & $\%$ red $^{\mathbf{a}}$ & Sprayed & Nonsprayed & $\%$ red $^{a}$ \\
\hline SC Nduna & 11.57 & 11.89 & -2.8 & 12.94 & 12.62 & 2.5 & 12.25 & 12.26 & -0.1 \\
\hline SC Stallion & 11.17 & 11.19 & -0.2 & 13.07 & 11.73 & $10.3^{+}$ & 12.12 & 11.46 & $5.4^{+}$ \\
\hline SC Sky & 10.59 & 10.96 & -3.5 & 12.82 & 13.18 & -2.8 & 11.71 & 12.07 & $-3.1^{+}$ \\
\hline Line $37-07$ & 11.25 & 9.95 & $11.6^{+}$ & 13.79 & 11.51 & $16.5^{+}$ & 12.52 & 10.73 & $14.3^{+}$ \\
\hline W1406 & 11.50 & 12.78 & $-11.1^{+}$ & 13.40 & 13.38 & 0.4 & 12.46 & 13.08 & $-4.8^{+}$ \\
\hline W6979 & 12.15 & 11.91 & 2.0 & 14.63 & 12.86 & $12.1^{+}$ & 13.39 & 12.38 & $7.4^{+}$ \\
\hline Kingbird & 11.18 & 12.08 & $-8.15^{+}$ & 13.99 & 13.30 & 4.9 & 12.59 & 12.69 & -0.8 \\
\hline Mean & 11.35 & 11.54 & -1.7 & 13.53 & 12.65 & $6.5^{+}$ & 12.44 & 12.10 & 2.7 \\
\hline Source & $\mathbf{s e}^{\mathbf{b}}$ & $\mathbf{L S D}^{\mathbf{c}}$ & F. Sigd & $\mathbf{s e}^{\mathbf{b}}$ & $\mathbf{L S D}^{\mathbf{c}}$ & F. Sig ${ }^{d}$ & $\mathbf{s e}^{\mathbf{b}}$ & $\mathbf{L S D}^{\mathrm{c}}$ & F. Sigd \\
\hline Treatment & 0.151 & 0.921 & NS & 0.096 & 0.585 & $*$ & 0.04 & 0.3 & $*$ \\
\hline Variety & 0.208 & 0.606 & $* * *$ & 0.261 & 0.762 & $* *$ & 0.18 & 0.5 & $* * *$ \\
\hline Year & & & & & & & 0.09 & 0.3 & $* * *$ \\
\hline Treatment*variety & 0.311 & 0.921 & $* *$ & 0.355 & 1.032 & $*$ & 0.24 & 0.7 & $* * *$ \\
\hline Treatment*year & & & & & & & 0.10 & 0.3 & $* * *$ \\
\hline Variety*year & & & & & & & 0.25 & 0.7 & NS \\
\hline Treatment*variety*year & & & & & & & 0.34 & 0.7 & NS \\
\hline
\end{tabular}


stem rust resistance, with only $Q S r$ - $u f s$ - $6 A$ having a major effect over seasons and locations. Lr34/Yr18/Sr57 and $Q S r-u f s-6 A$ had a smaller effect in W6979 than Lr34/Yr18/Sr57 and QSr-ufs-4D in W1406 (Prins et al. 2016). The differences in level of yield loss and disease scores are most likely due to seasonal effects influencing stem rust onset and development. Despite the confirmation of APR in Kenya Popo (W6979) in several studies (Bajgain et al. 2016; Macharia and Wanyera 2012; Njau et al. 2009; Prins et al. 2016), the stem rust phenotype of this line may vary depending on environmental conditions and amount of inoculum.

SC Sky showed effective, major-gene stem rust resistance both in the seedling and adult plant stages, which explained the low yield loss of $6.4 \%$ over two seasons. The TKW loss of $10.6 \%$ was the lowest among all lines, while HLM loss of $8.1 \%$ was higher than the APR lines W6979 and Kingbird. The high HLM reduction might have resulted in shriveled grains that caused less grain carbohydrates and a $3.1 \%$ gain in protein content (carbohydrates are directed to infected areas for growth) (Dubin and Brennan 2009; Roelfs 1985; Roelfs et al. 1992). SC Sky had a low infection type in previous greenhouse work (data not shown), and it had a stem rust field record of TR over two seasons in this study. SC Sky carries a combination of genes that includes $\mathrm{Sr} 2, \mathrm{Sr} 31, \mathrm{Lr} 19 / \mathrm{Sr} 25$, and the pleiotropic $\mathrm{Lr} 46 /$ Yr29/Sr58 gene (Soko 2018; Soko et al. 2015). The ASR gene(s) in SC Sky offered adequate protection against PTKST, resulting in less yield loss compared with lines that were only protected at the adult plant stage.

Effective and durable resistance in wheat varieties is the preferred way of providing protection against losses due to stem rust. The level of protection against stem rust is determined by the nature and number of both race specific (major) and nonrace specific (minor) genes that are combined in a variety. In the absence of corresponding virulence in the pathogen, SC Sky was less affected than the APR lines tested. However, when a resistance gene such as $\mathrm{Sr} 31$ is defeated as in SC Nduna, significant losses occur. In context with previous studies, the present work showed that APR can safeguard a variety against stem rust, but the level of protection may vary depending on gene complexities, environment, time of first rust occurrence, and inoculum pressure. Kingbird was not affected to the same degree as the other two APR lines, most likely as a result of the number of major QTL involved. It is also conceivable that certain QTL, by means of additive effects, will confer a lower rust phenotype than others.

Singh et al. (2011b) indicated that a single APR gene, when alone, does not confer adequate resistance especially under high disease pressure, but a combination of four to five such genes may result in near immunity or a high level of resistance. In the present study, not all APR lines performed similarly in terms of yield and yield components measured. Although extremely high inoculum levels were experimentally induced here, the possibility of such an event in a rust-conducive, commercial production cannot be ruled out completely. Breeding programs should thus embrace a combined APR and ASR approach to overcome the impact of Ug99 and other threatening rusts. If rust resistance is a breeding priority, it is important that commercial varieties be thoroughly characterized in terms of genotype and phenotype. By confirming complex resistance based on genes/QTL for which virulence is not known to exist, more informed predictions of durability become possible.

\section{Acknowledgments}

We thank Pannar Seed (Pty) Ltd. for hosting the trial and for assistance provided by Vicky Coetzee and Ash Babooram. We thank Seed-Co Ltd. and UFS for the germplasm used, and ARC-Small Grains, Bethlehem for assistance with grain protein analysis.

\section{Literature Cited}

AACC International. 1999. Approved Methods of Analysis, 11th Ed. Method 39-10.01 Near-Infrared Reflectance Method for Protein Determination in Small Grains. Approved November 3, 1999. AACC International, St. Paul, MN, U.S.A. http://dx.doi.org/10.1094/AACCIntMethod-39-10.01. www.aaccnet.org (16/6/17).

Bajgain, P., Rouse, M. N., Tsilo, T. J., Macharia, G. K., Bhavani, S., Jin, Y., and Anderson, J. A. 2016. Nested association mapping of stem rust resistance in wheat using genotyping by sequencing. PLoS One 11:e0155760.
Bhavani, S., Singh, R. P., Argillier, O., Huerta-Espino, J., Singh, S., and Njau, P. 2011. Mapping of durable adult plant stem rust resistance in six CIMMYT wheats to Ug99 group of races. BGRI Technical Workshop, June 13-16, St. Paul, USA.

Bhavani, S., Singh, R. P., Huerta-Espino, J., Singh, D., and Jin, Y. 2010. Mapping of Ug99 effective stem rust resistance genes Sr45 and SrNing on chromosomes 1DS and 4BL in CIMMYT wheat germplasm. $8^{\text {th }}$ International Wheat Conference, June 1-4, St. Petersburg, Russia.

Boshoff, W. H. P., Pretorius, Z. A., and Van Niekerk, B. D. 2003. Fungicide efficacy and the impact of stripe rust on spring and winter wheat in South Africa. S. Afr. J. Plant Soil 20:11-17.

Campbell, C. L., and Madden, L. V. 1991. Introduction to Plant Disease Epidemiology. John Wiley \& Sons, New York.

Cook, R. J., Hims, M. J., and Vaughan, T. B. 1999. Effects of fungicide spray timing on winter wheat disease control. Plant Pathol. 48:33-50.

Craven, M., Smith, K., Berner, J., Morey, L., and McLaren, N. W. 2017. Evaluation of fungicides for potential growth regulating properties on sorghum. Crop Prot. 101:43-49.

Cromey, M. G., Butler, R. C., Mace, M. A., and Cole, A. J. L. 2004. Effects of the fungicides azoxystrobin and tebuconazole on Didymella exitialis, leaf senescence and grain yield in wheat. Crop Prot. 23:1019-1030.

Dean, R., Van Kan, J. A. L., Pretorius, Z. A., Hammond-Kosack, K. E., Di Pietro, A., Spanu, P. D., Rudd, J. J., Dickman, M., Kahmann, R., Ellis, J., and Foster, G. D. 2012. The top 10 fungal pathogens in molecular plant pathology. Mol Plant Pathol. 13:414-430.

Dill-Macky, R., Rees, R. G., and Platz, G. J. 1990. Stem rust epidemics and their effects on grain yield and quality in Australian barley cultivars. Aust. J. Agric. Res. 41:1057-1063.

Dubin, H. J., and Brennan, J. P. 2009. Combating stem and leaf rust of wheat historical perspective, impacts and lessons learned. IFPRI Discussion Paper 00910, November 2009. www.ifpri.org/project/millions-fed.

Herrera-Foessel, S. A., Singh, R. P., Huerta-Espino, J., Crossa, J., Djurle, A., and Yuen, J. 2008. Genetic analysis of slow-rusting resistance to leaf rust in durum wheat. Crop Sci. 48:2132-2140.

Hiebert, C. W., Fetch, T. G., Jr., and Zegeye, T. 2010. Genetics and mapping of stem rust resistance to $\mathrm{Ug} 99$ in the wheat cultivar Webster. Theor. Appl. Genet. 121:65-69.

Hodson, D. P. 2011. Shifting boundaries: Challenges for rust monitoring. Euphytica 179:93-104.

Loughman, R., Jayasena, K., and Majewski, J. 2005. Yield loss and fungicide control of stem rust in wheat. Aust. J. Agric. Res. 56:91-96.

Macharia, J. K., and Wanyera, R. 2012. Effect of stem rust race Ug99 on grain yield and yield components of wheat cultivars in Kenya. J. Agric. Sci. Technol. A 2:423-431.

Mago, R., Brown-Guedira, G., Dreisigacker, S., Breen, J., Jin, Y., Singh, R., Appels, R. S., Lagudah, E. S., Ellis, J., and Spielmeyer, W. 2011. An accurate DNA marker assay for stem rust resistance gene Sr2 in wheat. Theor. Appl. Genet. 122:735-744.

Mukoyi, F., Soko, T., Mulima, E., Mutari, B., Hodson, D., Herselman, L., Visser, B., and Pretorius, Z. A. 2011. Detection of variants of wheat stem rust race Ug99 (Puccinia graminis f. sp. tritici) in Zimbabwe and Mozambique. Plant Dis. $95: 1188$

Njau, P. N., Jin, Y., Huerta-Espino, J., Keller, B., and Singh, R. P. 2010 Identification and evaluation of sources of resistance to stem rust race Ug99 in wheat. Plant Dis. 94:413-419.

Njau, P. N., Wanyera, R., Macharia, G. K., Macharia J., Singh R., and Keller, B. 2009. Resistance in Kenyan bread wheat to recent eastern African isolate of stem rust, Puccinia graminis f. sp. tritici, Ug99. J. Plant Breed. Crop Sci. 1: 022-027.

Olivera, P., Newcomb, M., Szabo, L. J., Rouse, M., Johnson, J., Gale, S., Luster, D. G., Hodson, D., Cox, J. A., Burgin, L., Hort, M., Gilligan, C. A., Mehran, P., and Justesen, A. F. 2015. Phenotypic and genotypic characterization of race TKTTF of Puccinia graminis f. sp. tritici that caused a wheat stem rust epidemic in southern Ethiopia in 2013-14. Phytopathology 105:917-928.

Olivera Firpo, P. D., Newcomb, M., Flath, K., Sommerfeldt-Impe, N., Szabo, L. J., Carter, M., Luster, D. G., and Jin, Y. 2017. Characterization of Puccinia graminis f. sp. tritici isolates derived from an unusual wheat stem rust outbreak in Germany in 2013. Plant Pathol. 66:1258-1266.

Park, R. F. 2007. Stem rust of wheat in Australia. Aust. J. Agric. Res. 58:558-566

Pretorius, Z. A., Ayliffe, M., Bowden, R. L., Boyd, L. A., DePauw, R. M., Jin, Y., Knox, R. E., McIntosh, R. A., Park, R. F., Prins, R., and Lagudah, E. S. 2017 Advances in control of wheat rusts. Pages 295-343 in: Achieving Sustainable Cultivation of Wheat, Vol. 1: Breeding, Quality Traits, Pests and Diseases. P. Langridge, ed. Burleigh Dodds Science Publishing, Cambridge.

Pretorius, Z. A., and Bender, C. M. 2010. First report of virulence for the wheat leaf rust (Puccinia triticina) resistance gene Lr32 in South Africa. Plant Dis. 94:381

Pretorius, Z. A., Pakendorf, K. W., Marais, G. F., Prins, R., and Komen, J. S. 2007. Challenges for sustainable cereal rust control in South Africa. Aust. J. Agric. Res. 58:593-601.

Pretorius, Z. A., Singh, R. P., Wagoire, W. W., and Payne, T. S. 2000. Detection of virulence to wheat stem rust resistance gene Sr31 in Puccinia graminis f. sp. tritici in Uganda. Plant Dis. 84:203.

Pretorius, Z. A., Visser, B., Terefe, T., Herselman, L., Prins, R., Soko, T., Siwale, J., Mutari, B., Selinga, T. I., and Hodson, D. P. 2015. Races of Puccinia triticina 
detected on wheat in Zimbabwe, Zambia and Malawi and regional germplasm responses. Aust. Plant Pathol. 44:217-224.

Prins, R., Dreisigacker, S., Pretorius, Z., van Schalkwyk, H., Wessels, E., Smit, C., Bender, C., Singh, D., and Boyd, L. A. 2016. Stem rust resistance in a geographically diverse collection of spring wheat lines collected from across Africa. Front. Plant Sci. 7:973-987.

Roelfs, A. P. 1982. Effects of barberry eradication on stem rust in the United States. Plant Dis. 66:177-181.

Roelfs, A. P. 1985. Wheat and rye stem rust. Pages 3-27 in: The Cereal Rusts, Vol. II, Diseases, Distribution, Epidemiology and Control. A. P. Roelfs and W. R. Bushnell, eds. Academic Press, Orlando, FL.

Roelfs, A. P., Singh, R. P., and Saari, E. E. 1992. Rust Diseases of Wheat: Concepts and Methods of Disease Management. CIMMYT, D.F., Mexico.

Singh, R. P., Hodson, D. P., Huerta-Espino, J., Jin, Y., Bhavani, S., Njau, P., Herrera-Foessel, S., Singh, P. K., Singh, S., and Velu, G. 2011a. The emergence of $\mathrm{Ug} 99$ races of the stem rust fungus is a threat to world wheat production. Annu. Rev. Phytopathol. 49:465-481.

Singh, R. P., Hodson, D. P., Huerta-Espino, J., Jin, Y., Njau, P., Wanyera, R., Herrera-Foessel, S. A., and Ward, R. W. 2008. Will stem rust destroy the world's wheat crop? Adv. Agron. 98:271-309.

Singh, R. P., Hodson, D. P., Jin, Y., Huerta-Espino, J., Kinyua, M. G., Wanyera, R., Njau, P., and Ward, R. W. 2006. Current status, likely migration and strategies to mitigate the threat to wheat production from race Ug99 (TTKS) of stem rust pathogen. CAB Reviews: Perspectives in Agriculture, Veterinary Science, Nutrition and Natural Resources 1, No. 054.

Singh, R. P., Hodson, D. P., Jin, Y., Lagudah, E. S., Ayliffe, A. M., Bhavani, S., Rouse, M. N., Pretorius, Z. A., Szabo, L. J., Huerta-Espino, J., Basnet, B. R.,
Lan, C., and Hovmøller, M. S. 2015. Emergence and spread of new races of wheat stem rust fungus: Continued threat to food security and prospects of genetic control. Phytopathology 105:872-884.

Singh, R. P., Huerta-Espino, J., Bhavani, S., Herrera-Foessel, S. A., Singh, D., Singh, P. K., Velu, G., Mason, R. E., Jin, Y., Njau, P., and Crossa, J. 2011b. Race non-specific resistance to rust diseases in CIMMYT spring wheats. Euphytica 179:175-186.

Soko, T. 2018. Stem rust resistance and yield performance of irrigated Zimbabwean spring wheat. Ph.D. thesis. University of the Free State, Bloemfontein, South Africa.

Soko, T., Prins, R., and Pretorius, Z. A. 2015. Are Zimbabwean wheat cultivars protected against $P g t$ race Ug99? BGRI Technical workshop, September 1720, Sydney, Australia.

Terefe, T. G., Visser, B., and Pretorius, Z. A. 2016. Variation in Puccinia graminis f. sp. tritici detected on wheat and triticale in South Africa from 2009 to 2013. Crop Prot. 86:9-16.

Wanyera, R., Wamalwa, M., Odemba, M., Wanga, H., Kinyanjui, P., Onyango, V. and Owuocha, J. 2016. Management of wheat rusts at different growth stages using Nativo 300 SC (trifloxystrobin $100 \mathrm{~g} / \mathrm{L}$ + tebuconazole 200g/L) fungicide. Aust. J. Crop Sci. 10:1273-1280.

Wu, Y.-X., and Von Tiedemann, A. 2001. Physiological effects of azoxystrobin and epoxiconazole on senescence and the oxidative status of wheat. Pestic. Biochem. Physiol. 71:1-10.

Yu, L.-X., Lorenz, A., Rutkoski, J., Singh, R. P., Bhavani, S., Huerta-Espino, J., and Sorrell, M. E. 2011. Association mapping and gene-gene interaction for stem rust resistance in CIMMYT spring wheat germplasm. Theor. Appl. Genet. 123:1257-1268. 